\title{
STRUCTURAL AND FUNCTIONAL CHANGES IN A GENERATION IN TETRAHYMENA ${ }^{1}$
}

\author{
GEORGE G. HOLZ, JR. \\ Department of Zoology, Syracuse University, Syracuse, N. Y.
}

With the development of techniques for synchronizing the division of members of a population of microorganisms, it has become possible to analyze many changes that occur in a cell during a generation (the period from the end of one division to the end of the next). The ciliate protozoan Tetrahymena pyriformis has been used in this way by Zeuthen and his coworkers in studies directed at biochemical changes; nitrogen content (Hamburger and Zeuthen, 1958), nucleoside triphosphate concentration (Plesner, 1958a), rate of incorporation of $\mathrm{P}^{32}$ (Hamburger and Zeuthen, 1958), and sensitivity to anaerobiosis (Rasmussen, 1958), dinitrophenol (Hamburger and Zeuthen, 1957), and inhibitors of oxidative metabolism (Hamburger, 1958). Synchronously-dividing populations are also useful for tracing the time course of structural changes. Tetrahymena is uniquely suited to such a study since it passes through a period of morphogenesis in each generation that results in duplication of the structures necessary for the formation of a new individual before division (body cilia, mouth, contractile vacuoles, cytopyge) (Chatton et al., 1931; Furgason, 1940), and it undergoes nuclear changes involving a mitotic division of the micronucleus and an amitotic division of the macronucleus (Maupas, 1883, 1888).

The following is a description of the time course of the structural changes (those visible with the light microscope) in a generation, in a synchronized population of Tetrahymena pyriformis, mating type I, variety 1 , and a comparison of it with the time course of known chemical changes in a generation, observed with other strains of Tetrahymena.

\section{Materials And Methods}

Division was synchronized by the application of 5 alternate $1 / 2$-hour exposures to temperatures of $42.6 \pm 0.2^{\circ} \mathrm{C}$. and $35 \pm 0.2^{\circ} \mathrm{C}$. Other details of procedure were as described by Holz, Scherbaum and Williams (1957). Following the final high temperature period, samples of ciliates were withdrawn at 5-minute intervals for 180 minutes. To determine when the first and second synchronous divisions occurred, the division index (cells in division $\div$ cells counted) was measured for each sample. The first synchronous division (70-80\% synchrony) occurred 50-60 minutes after the last high temperature period, and the second division (45-55\% synchrony) 65-75 minutes after the first division. Changes in the nuclear apparatus (Fig. 1), infraciliature (Fig. 8), and general appearance of the ciliates during the interval between divisions were followed by Feulgen-staining (Dippell

1 This work was supported by Grant E-797 of the National Institute of Allergy and Infectious Diseases, U. S. Public Health Service, to G. G. Holz, Jr. 
and Chao's modification of the DeLamater stain; Sonneborn, 1950), silver impregnation (Chatton-Lwoff technique; Corliss, 1953), and the observation of living individuals with a phase contrast microscope. The temporal positions of the nuclear and morphogenetic events in a generation were determined by comparisons of the times of greatest frequency of appearance of these events (in the samples taken between the first and second synchronous divisions) with the times when the first and second synchronous divisions occurred.

To establish a basis for comparison of the times of structural changes in mating type I, variety 1 , with the times of changes in physiological and biochemical parameters reported for other strains, all generation times of the various strains used were compressed to 100 arbitrary units and the time courses of all changes adjusted to fit this scale. For synchronously-dividing cells, the generation time used in these calculations was that of the synchronous generation during which observation of a particular structural or functional change was made. With one exception this was the second synchronous generation (the period between the first and second synchronous divisions). Nucleoside triphosphate content was determined at various times during the first synchronous generation (the period from the end of the last high temperature exposure to the first synchronous division) (Plesner, 1958a). Data on DNA synthesis (McDonald, 1958) and sensitivity to extremes of temperature (Thormar, 1956) were obtained with single normal cells, nitrogen content (Hamburger and Zeuthen, 1958), sensitivity to dinitrophenol (Hamburger and Zeuthen, 1957), sensitivity to inhibitors of oxidative metabolism (Hamburger, 1958), nucleoside triphosphate content (Plesner, 1958a), and rate of incorporation of $\mathrm{P}^{32}$ (Hamburger and Zeuthen, 1958) were measured with groups of synchronized cells, and rate of respiration (Zeuthen, 1953 ; Zeuthen and Scherbaum, 1954) and sensitivity to anaerobiosis (Rasmussen, 1958) with both types. Such a comparison is based on several assumptions: first, that there are no gross differences in the time scales of structural and functional events in a generation in different strains of Tetrahymena pyriformis with different generation times and nuclear constitutions (micronucleate and amicronucleate), i.e., that each event occurs at the same relative time in every strain; second, that the time characteristics of structural and functional changes occurring between synchronous divisions can be compared with those occurring between divisions of normal cells (cells that have not been heat-treated).

The first assumption is made on the basis that the structural and chemical changes that have been studied are of such a fundamental nature, necessary to the orderly progression of growth and preparation for division, that they probably follow the same relative time courses in all strains. This assumption was tested experimentally, so far as structural changes were concerned, by comparing the time courses of morphogenetic and macronuclear changes in strain GL and in mating type I, variety 1, with synchronized populations. Strain GL was synchronized by the method of Scherbaum and Zeuthen (1954). Comparison was also made of the time course of structural changes of mating type $I$, variety 1 , with that reported by Browning, Varnedoe and Swinford (1952) for strain T-P. McDonald (1958) and Prescott and Bors (1958), using different strains, reached fundamentally the same conclusion concerning the period of DNA synthesis in a generation. 

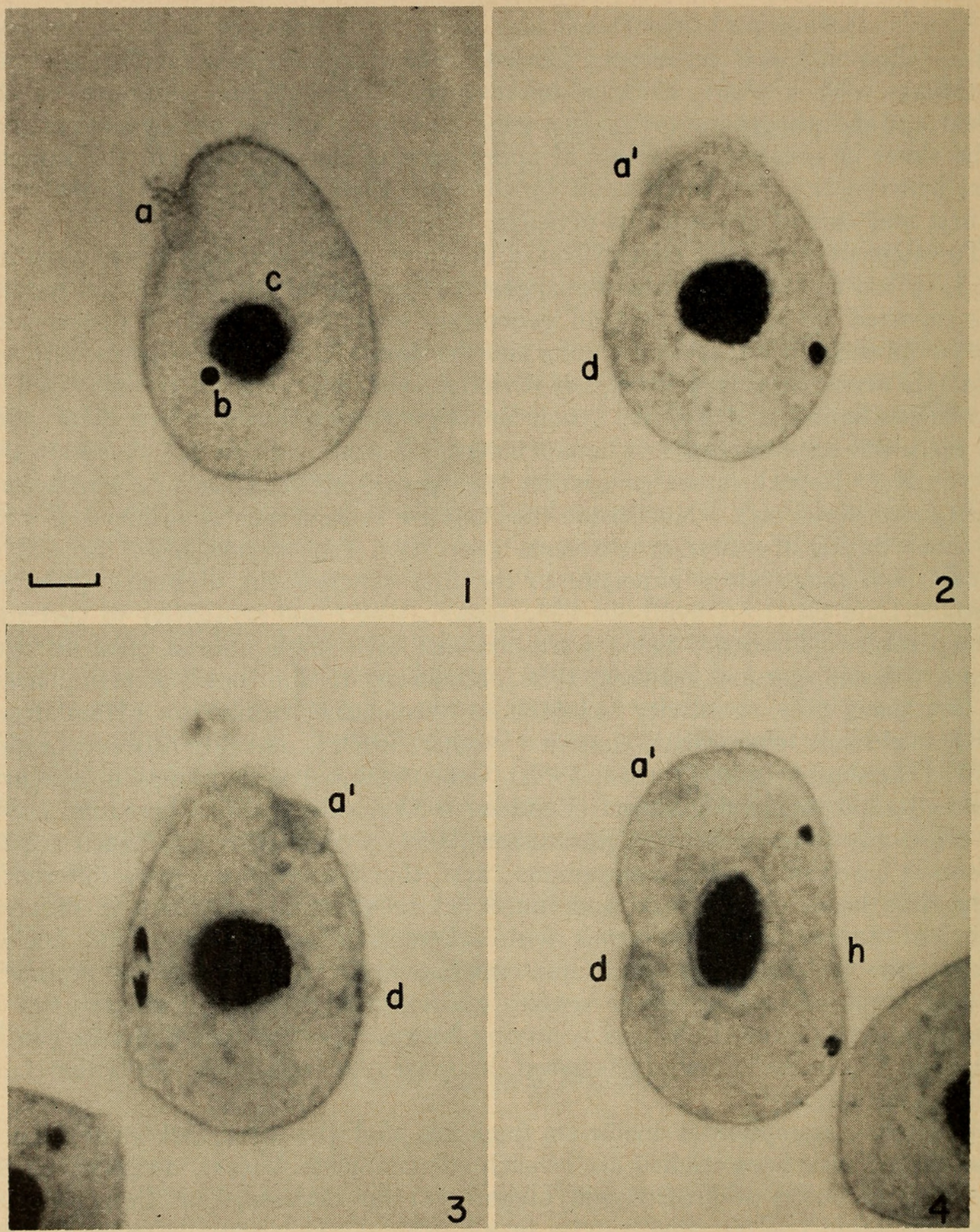

FIGURE 1. Resting nuclear configuration in Tetrahymena pyriformis, mating type I, variety 1. In this and the following illustrations of nuclear states, ciliates were not destained to a degree necessary to bring out fine nuclear detail. This was done to insure visualization of the cilia of the mouth, to assist in observing time relations of nuclear and morphogenic states. The marker indicates $10 \mu$ for Figures 1-7.

Figure 2. Stage of macronuclear enlargement. The micronucleus is peripherally located. Cilia of the forming mouth of the opisthe are seen.

Figure 3. Micronuclear anaphase.

Figure 4. Micronuclear division complete. Macronuclear division and cytoplasmic cleavage beginning. 
The second assumption is more open to question. Cells prepared for synchronous division by the temperature-cycling method have a shorter generation time (Zeuthen and Scherbaum, 1954), have a greater volume (Scherbaum, 1956), greater reduced weight (Scherbaum and Zeuthen, 1954), greater dry weight (Scherbaum, 1957b), and contain more nitrogen (Zeuthen and Hamburger, 1956), DNA and RNA (Scherbaum, 1957b), ATP and GTP (Plesner, 1956, 1958b) than do normal cells. During the synchronous divisions these characteristics return to normal. To liken the time courses of biochemical changes that have been studied in these cells to the condition in normal cells, we must assume that the differences noted above influence only the extent of the changes studied and not their time characteristics with respect to division. In this connection, it is notable that rate of respiration (Zeuthen, 1953; Zeuthen and Scherbaum, 1954) and sensitivity to anaerobiosis (Rasmussen, 1958) follow the same time courses between divisions in heat-treated and normal cells. The chemical composition of the heattreated cells might cause the morphogenetic and nuclear changes to follow different time courses with respect to one another. To test this possibility, synchronized cells, and normal cells from cultures reproducing at an exponential rate, were compared for nuclear state in silver impregnations showing stages of stomatogenesis. In such preparations the micronucleus shows up well except during its final division stages.

\section{Results}

The resting micronucleus was spherical and lay next to the macronucleus, or within a cup-shaped depression in the macronucleus (Fig. 1). The resting state was assumed immediately after completion of cytoplasmic cleavage and lasted for about $75 \%$ of a generation. At the end of this period the micronucleus moved laterally toward the periphery of the organism and elongated (Fig. 2). Chromosomes appeared at this time. The most clearly recognizable stages of mitosis were those associated with separation of the chromosomes (Fig. 3). As the chromosomes reached the poles of the division figure the latter greatly elongated and the micronucleus was divided into halves which became separated respectively into the anterior and posterior parts of the dividing organism (Fig. 4). These daughter micronuclei then became spherical again. The division of the micronucleus went to completion as macronuclear division and cytoplasmic cleavage began.

Key to Figures $1-16$

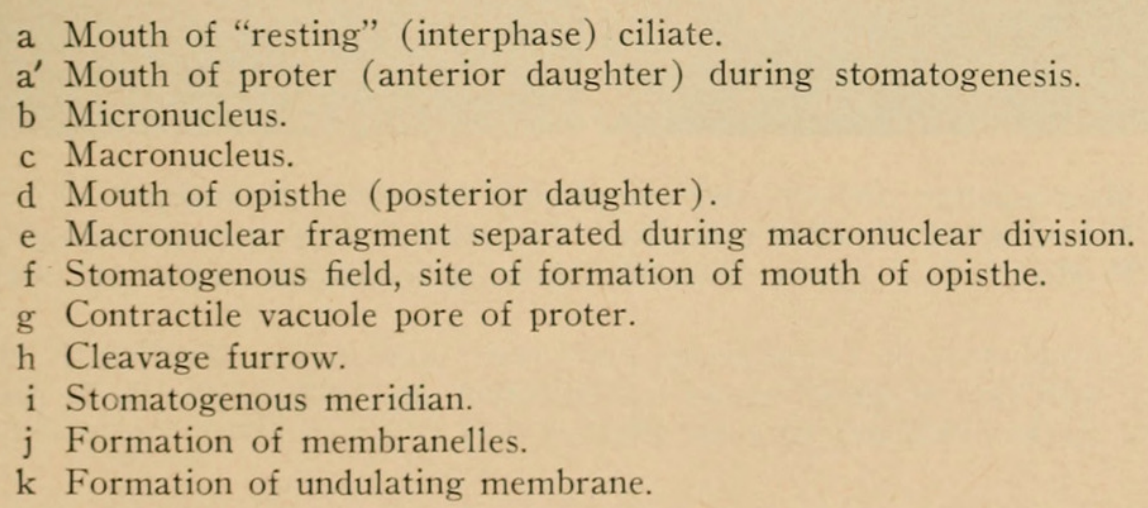



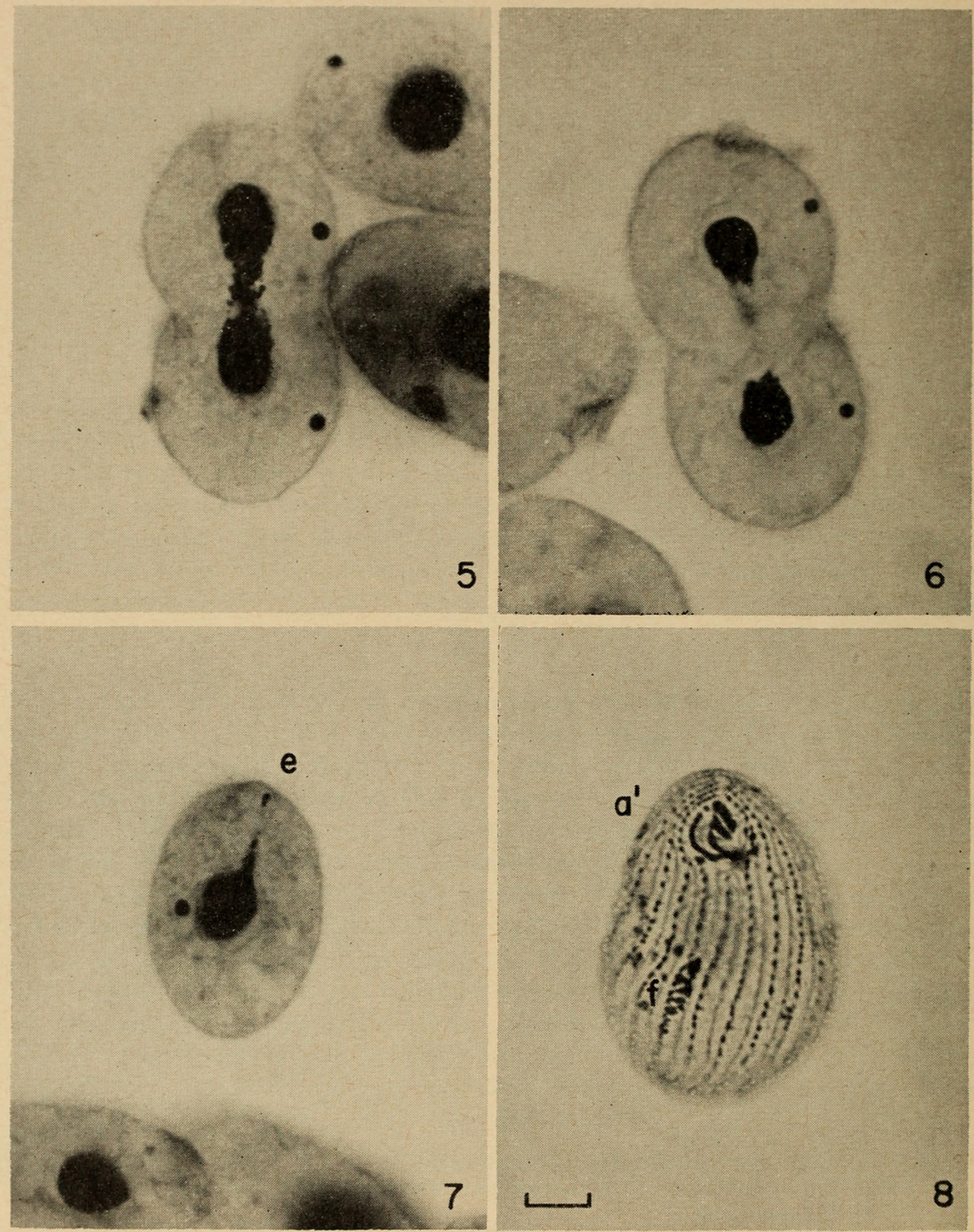

FIGURE 5. Macronuclear division and cytoplasmic cleavage continuing.

Figure 6. Macronuclear division complete. Cytoplasmic cleavage continuing.

Figure 7. Product of a recent division, showing re-establishment of resting nuclear configuration.

FIgURE 8. Infraciliature of Tetrahymena pyriformis, mating type I, variety 1 . Note normal mouth of proter with typical tetrahymenal configuration, and stomatogenesis to produce mouth of opisthe. The marker indicates $10 \mu$ for Figures 8-11. 

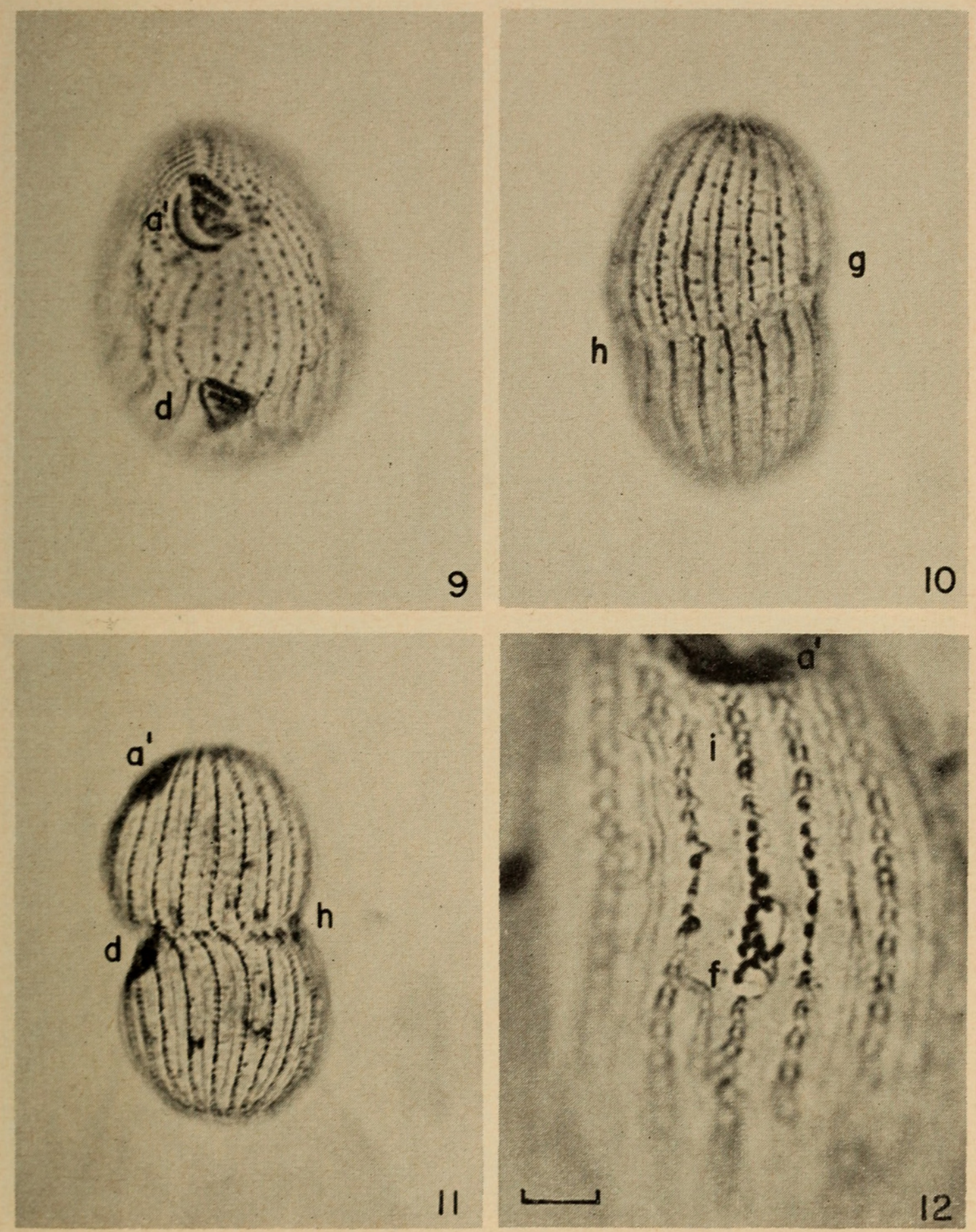

Figure 9. Completion of stomatogenesis in opisthe.

FIGURE 10. Appearance of cleavage furrow at beginning of division (dorsal surface of ciliate). Note contractile vacuole pore of opisthe just anterior to furrow on right side of animal.

Figure 11. Cleavage.

FigURE 12. Very early stage of stomatogenesis. Kinetosomes appear to left (animal's left) of stomatogenous meridian. The marker indicates $5 \mu$ for Figures 12-16. 

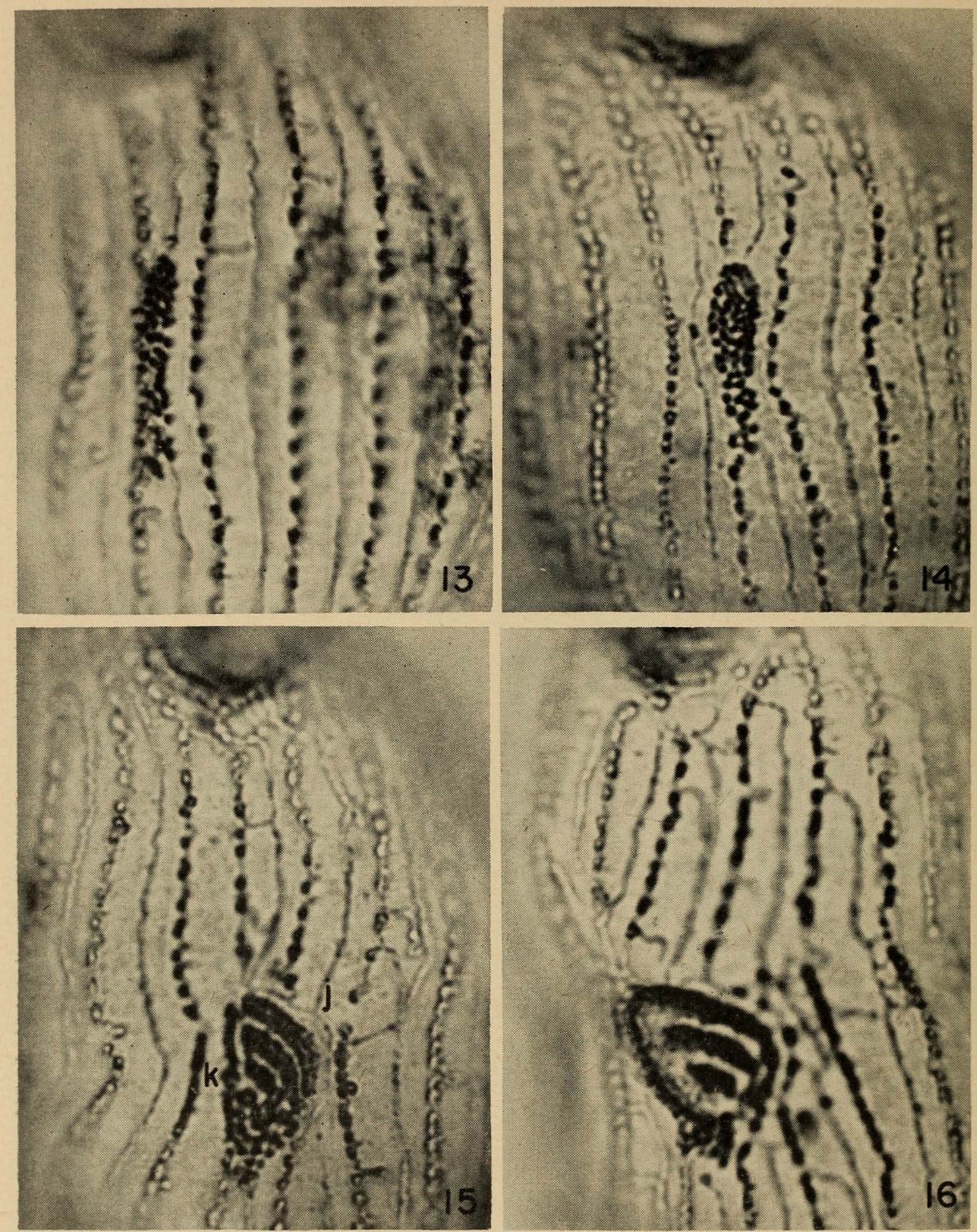

FigURE 13. Stomatogenesis; anarchic field.

FIGURE 14. Stomatogenesis. Very early stage of membranelle organization at anterior end of field.

FIgURE 15. Stomatogenesis. Three membranelles and undulating membrane formed.

FIGURE 16. Stomatogenesis; terminal stage.

The macronucleus was an approximately spherical, centrally-located structure (Fig. 1). Immediately after cleavage, it assumed a resting state characterized by a moderately dense and homogeneous granular appearance. At the time the micronucleus migrated to the periphery of the organism, the macronucleus in- 
creased in size and granularity (Fig. 2). As the micronucleus divided, the macronucleus elongated (Fig. 4), and at the time the cleavage furrow separated the daughter ciliates, it divided into approximately equal halves (Figs. 5 and 6). Small portions of the macronucleus occasionally separated from the main macronuclear masses at this time and became isolated in the cytoplasm as spherical, Feulgen-positive bodies which were later resorbed (Furgason, 1940; Scherbaum et al., 1958).

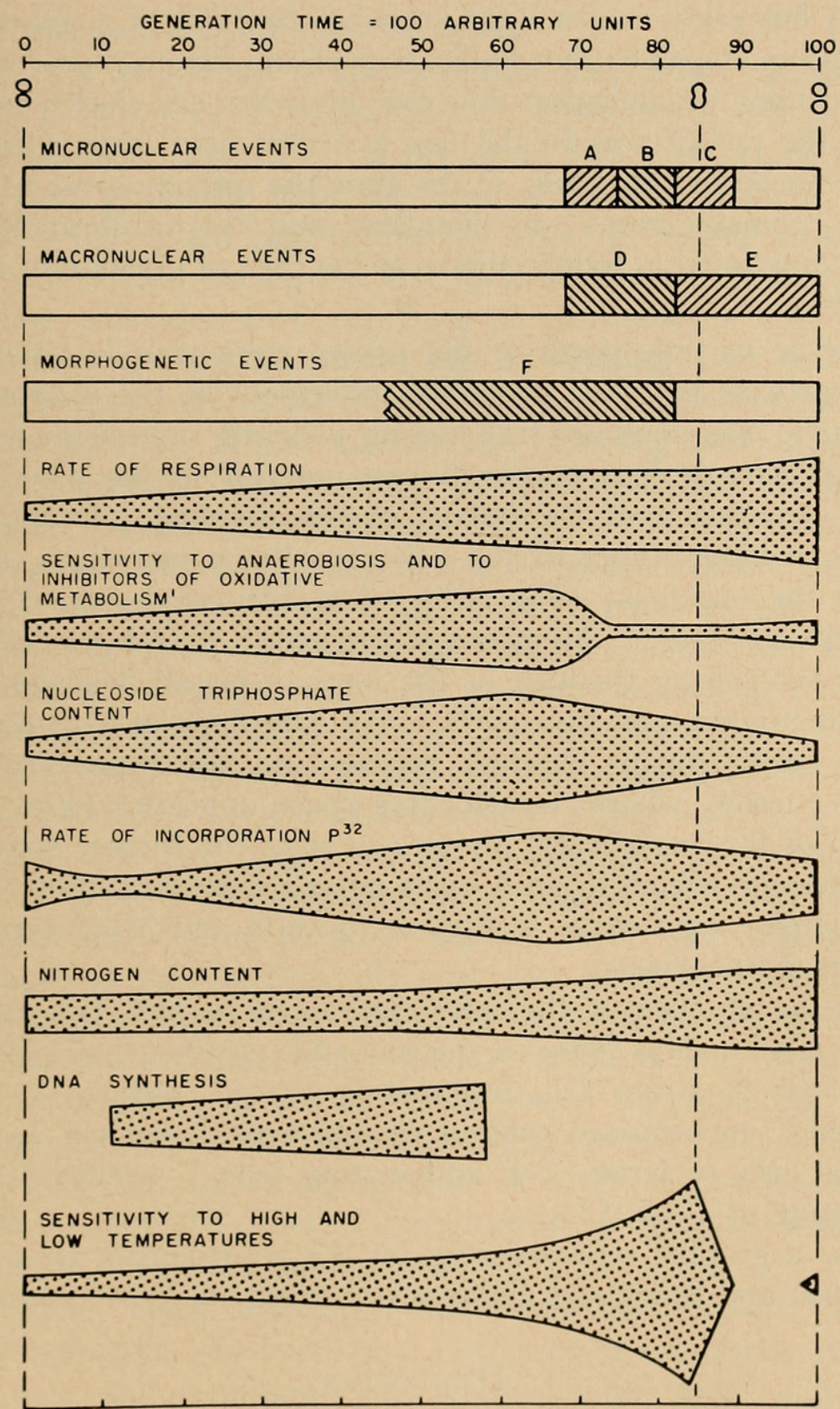

FIGURE 17. Graphic representation of approximate time relationships of structural and functional changes occurring in Tetrahymena pyriformis in a generation. (A-migration of micronucleus to periphery, B-mitosis, C-separation of products of mitosis into daughters, D-macronuclear swelling, E-macronuclear division, F-stomatogenesis, 1-nitrogen ; Rasmussen, 1958, dinitrophenol; Hamburger and Zeuthen, 1957, fluoride, fluoracetate, azide, ethylurethane; Hamburger, 1958). 
Morphogenesis in Tetrahymena involves formation of new body cilia, a new mouth (stomatogenesis) for the posterior daughter (opisthe), and new contractile vacuole pores and a cytopyge (cell anus) for the anterior daughter (proter). Body cilia are duplicated at a time not yet precisely determined. Stomatogenesis (mouth formation) was manifested first by the appearance of kinetosomes (basal bodies of cilia) to the left of the stomatogenous kinety (row of cilia, or primary ciliary meridian, passing posteriorly from the right side of the buccal overture) near the middle of the body (Fig. 8). The precise time when stomatogenesis began was not determined but early stages were seen before $45 \%$ of a generation was completed. Successive stages in the duplication of the kinetosomes of the cilia of the new mouth and their organization into membranelles are shown in Figures 12-16. The anlage of the mouth was in the late anarchic field stage (Fig. 14), or early stage of membranelle organization, at the time the micronucleus assumed a peripheral position. Stomatogenesis was complete, and the membranelles of the mouth appeared to be functional in living ciliates at the time of division of the micronucleus. (Figs. 9, 15, 16).

The contractile vacuole pores of the proter were seen in silver impregnations (Fig. 10) as early as the time of lateral movement of the micronucleus, and the contractile vacuole was observed functioning in living organisms at this time.

The cleavage furrow first appeared just anterior to the mouth of the opisthe at the time of separation of the halves of the dividing micronucleus. A space appeared between kinetosomes of the primary ciliary meridians, in a line around the equator of the organism (Fig. 10). The furrow deepened until the proter and opisthe were separated. Members of the genus Tetrahymena should be excellent organisms for testing theories of the mechanism of cleavage since they have markers, the kinetosomes, in the cortex. An examination of the pattern of infraciliature in the cortex during cleavage revealed no distortion except in the region of the cleavage furrow, where the cilia-free space appeared (Fig. 10), and where a slight torsion of the ends of the kineties next to the furrow sometimes occurred (Fig. 11). Theories which depend upon polar expansions (active or passive) of the cortex accompanying furrow formation (Swann and Mitchison, 1958) seem to be untenable for Tetrahymena.

Except for the absence of the micronucleus in strains GL and T-P, no differences in the relationships between nuclear and morphogenetic events were noted when normal cells of strain GL and mating type I, variety 1, were compared, when normal and synchronized cells of mating type I, variety 1 , were compared, or when normal cells of strain T-P and mating type $\mathrm{I}$, variety 1 , were compared (data of Browning et al., 1952).

Figure 17 is a graphic representation of the approximate time relationships of various structural and functional changes occurring in Tetrahymena pyriformis in a generation.

\section{Discussion}

As noted by Zeuthen (1958), there are striking associations between those biochemical changes related to energy production, and the initiation and completion of nuclear events associated with division and the process of cytoplasmic cleavage. Rate of respiration, sensitivity to anaerobiosis and to dinitrophenol and inhibitors of oxidative metabolism, nucleoside triphosphate content, and rate of $\mathrm{P}^{32}$ incorpora- 
tion reach a maximum at the time of initiation of nuclear events. During the following period of nuclear changes, before the appearance of the cleavage furrow, the rate of respiration remains high and constant, sensitivity to anaerobiosis and to dinitrophenol and inhibitors of oxidative metabolism are at a minimum, and nucleoside triphosphate content and the rate of incorporation of $\mathrm{P}^{32}$ decline. When the cleavage furrow appears, sensitivity to anaerobiosis and to dinitrophenol and inhibitors of oxidative metabolism begins to rise, while nucleoside triphosphate content and the rate of $\mathrm{P}^{32}$ incorporation continue to decline. As cleavage proceeds, the rate of respiration begins to rise again.

The last $25 \%$ of a generation is also a period that shows the greatest fluctuations in sensitivity to extremes of temperature. Sensitivity is at a minimum during the final $2 / 3$ of cytoplasmic cleavage. It begins to rise just before the completion of cleavage and rises gradually until the time of nuclear changes, when it rises abruptly to reach a maximum just before the onset of visible cleavage. It then drops sharply to a minimum during the first $1 / 3$ of cleavage (Thormar, 1956). The most sensitive time coincides with the time of chromosome movement and the elongation of the micronucleus accompanying its division, just before the macronucleus begins to elongate, and at the time of final organization of the membranelles of the mouth of the opisthe. These nuclear and morphogenetic stages are characteristic of ciliates prevented from dividing by the cyclic heat treatments used to induce synchronous division (Holz et al., 1957). The high sensitivity is not attributable to the effects of temperature on micronuclear division, since the amicronucleate strain GL seems to be blocked at the same point in time (Williams and Scherbaum, 1959). It is not possible at present to associate the high sensitivity of this period with any one of the coincident processes occurring (nuclear changes, morphogenetic changes, preparation for cytoplasmic cleavage). The cyclic heat treatments do not prevent the early stages of mitosis, amitosis or stomatogenesis, but do stop these processes at very characteristic stages and have no differential effect on them such that one progresses in time beyond the others. In normal cells from cultures which are reproducing at an exponential rate, nuclear changes and stomatogenesis also follow parallel courses, with time characteristics such that the early stages of micronuclear division, just prior to macronuclear elongation, and the late anarchic field stage and early stages of membranelle organization coincide. The fact that mitosis, macronuclear division and stomatogenesis are blocked by high temperature at characteristic stages suggests that the heat-labile biochemical system (systems) postulated by Scherbaum (1957a) and by Zeuthen (1958) is (are) necessary to the completion of all these processes, or that each process is dependent upon the others for its normal progression and goes to completion only when the others are unimpaired.

McDonald (1958), using a Feulgen microspectrophotometric method on the macronuclei of single cells, observed that DNA synthesis began after passage of about $10 \%$ of a generation, continued for approximately $45 \%$, and ended shortly before the initiation of nuclear structural changes. In a recent preliminary note Prescott and Bors (1958) report a slightly shorter period of synthesis starting at about the same relative time and ending midway in the generation. They followed the course of synthesis by autoradiographic detection of the incorporation of tritiated thymidine. These findings are not in agreement with the earlier report 
of Walker and Mitchison (1957) that a linear synthesis occurs throughout interphase. Duplication of DNA in the first half of a generation is not characteristic of all ciliates. Euplotes eurystomus (Fauré-Fremiet et al., 1957), Paramecium caudatum (Walker and Mitchison, 1957), and Paramecium aurelia (Kimball and Barka, 1959) synthesize their DNA during the last half of a generation.

The author wishes to acknowledge with thanks the helpful suggestions of Dr. Verner Wulff and Dr. Eric Zeuthen.

\section{SumMARY}

The time courses of structural events occurring in a synchronous generation of $T$. pyriformis, mating type $I$, variety 1 , were compared with one another and with the time courses of functional events in a synchronous generation, and/or in a generation of single, normal ciliates, of other strains of the species.

\section{Note Added in Proof}

Since this manuscript was accepted for publication two important relevant papers have appeared. Scherbaum et al., J. Cell. Comp. Physiol., 53: 119-138, 1959, reported that in strain GL the pattern of protein amino acids at stages in normal growth, and during the first synchronous generation of heat-treated cells, was stable. The free amino acids present at the same stages varied in their concentrations, but not in a manner that could be correlated with any of the cytological changes that occurred. Scherbaum et al., Exp. Cell Res., 18: 150-166, 1959, reported that in strain GL, during the first synchronous generation (end of heattreatment to onset of first synchronous division), the dry weight, volume, acidsoluble phosphates, acid-insoluble heat-labile phosphates, and DNA content of the average cell increased, and thymidine incorporation into DNA could be demonstrated. In addition, circumstantial evidence from microspectrophotometric experiments, indicated a burst of DNA synthesis just prior to and during the first synchronous division. As the authors suggested, substantiation of this finding would make it unwise to apply information on DNA synthesis obtained with synchronized cells to the process in normal cells.

\section{LITERATURE CITED}

Browning, I., N. B. Varnedoe and L. R. Swinford, 1952. Time of nuclear, cytoplasmic and cortical division of the ciliated protozoan Tetrahymena geleii. J. Cell. Comp. Physiol., 39: 371-381.

Chatton, E., A. Lwoff and J. L. Monod, 1931. La formation l'ébauche buccale postérieure chez les cilies en division et ses relations de continuité topographique et génétique avec la bouche antérieure. C. R. Soc. Biol., 107: 540-544.

Corliss, J. O., 1953. Silver impregnation of ciliated protozoa by the Chatton-Lwoff technique. Stain Technol., 28 : 97-100.

Fauré-Fremiet, E., C. Rouiller and M. Gauchery, 1957. La réorganisation macronucléaire chez les Euplotes. Etude au microscope électronique. Exp. Cell Res., 12: 135-144.

Furgason, W. H., 1940. The significant cytostomal pattern of the "Glaucoma-Colpidium group," and a proposed new genus and species, Tetrahymena geleii. Arch. f. Protistenk., $94: 224-266$.

Hamburger, K., 1958. Cited in Zeuthen, E., 1958. Periodicity in living cells. Adv. Biol. Med. Phys., 6: 37-73. 
Hamburger, K., and E. Zeuthen, 1957. Synchronous divisions in Tetrahymena pyriformis as studied in an inorganic medium. The effect of 2,4-dinitrophenol. Exp. Cell Res., 13: $443-453$.

Hamburger, K., and E. Zeuthen, 1958. Cited in Zeuthen, E., 1958. Periodicity in living cells. Adv. Biol. Med. Phys., 6: 37-73.

Holz, G. G., O. H. Scherbaum and N. Williams, 1957. The arrest of mitosis and stomatogenesis during temperature-induction of synchronous division in Tetrahymena pyriformis, mating type I, variety 1 . Exp. Cell Res., 13: 618-621.

Kimball, R. F., and T. Barka, 1959. Quantitative cytochemical studies on Paramecium aurelia. II. Feulgen microspectrophotometry of the macronucleus during exponential growth. Exp. Cell Res., 17: 173-182.

Maupas, E., 1883. Contributions à l'étude morphologique et anatomique des infusoires ciliés. Arch. Zool. Exp. Gén. (sér. 2), 1: 427-664.

Maupas, E., 1888. Recherches experimentales sur la multiplication des infusoires ciliés. Arch. Zool. Exp. Gén. (sér. 2), 6: 165-277.

McDonald, B. B., 1958. Quantitative aspects of deoxyribose nucleic acid (DNA) metabolism in an amicronucleate strain of Tetrahymena. Biol. Bull., 114: 71-94.

Plesner, P., 1956. Incorporation of $\mathrm{P}^{32}$ into the purine ribonucleotides of Tetrahymena pyriformis in heat-treated cultures. Acta Chem. Scand., 10: 161-162.

Plesner, P., 1958a. The nucleoside triphosphate content of Tetrahymena pyriformis during the division cycle in synchronously dividing mass cultures. Biochem. Biophys. Acta, 29: 462-463.

Plesner, P., 1958b. Cited in Zeuthen, E., 1958. Periodicity in living cells. Adv. Biol. Med. Phys., 6: 37-73.

Prescott, D. M., and K. Bors, 1958. Synthesis of protein, ribonucleic acid and desoxyribonucleic acid over the cell cycle. Anat. Rec., 132: 489.

Rasmussen, L., 1958. Cited in Zeuthen, E., 1958. Periodicity in living cells. Adv. Biol. Med. Phys., 6: 37-73.

Scherbaum, O., 1956. Cell growth in normal and synchronously dividing mass cultures of Tetrahymena pyriformis. Exp. Cell Res., 11: 464-476.

Scherbaum, O., 1957a. Studies on the mechanism of synchronous cell division in Tetrahymena pyriformis. Exp. Cell Res., 13: 11-23.

Scherbaum, O., 1957b. The content and composition of nucleic acids in normal and synchronously dividing mass cultures of Tetrahymena pyriformis. Exp. Cell Res., 13: 24-30.

Scherbaum, O., and E. Zeuthen, 1954. Induction of synchronous cell division in mass cultures of Tetrahymena pyriformis. Exp. Cell Res., 6: 221-227.

Scherbaum, O. H., A. L. Louderback and T. L. Jahn, 1958 . The formation of subnuclear aggregates in normal and synchronized protozoan cells. Biol. Bull., 115: 269-275.

Sonneborn, T. M., 1950. Methods in the general biology and genetics of Paramecium aurelia. J. Exp. Zool., $113: 87-143$.

Swann, M. M., And J. M. Mitchison, 1958. The mechanism of cleavage in animal cells. Biol. Revs., 33: 103-135.

Thormar, H., 1956. Cited in Zeuthen, E., 1958. Periodicity in living cells. Adv. Biol. Med. Phys., 6: 37-73.

Walker, P. M. B., and J. M. Mitchison, 1957. DNA synthesis in two ciliates. Exp. Cell Res., $13: 167-170$.

Williams, N., And O. H. Scherbaum, 1959. Morphogenetic events in normal and synchronously dividing Tetrahymena pyriformis. J. Embryol. Exp. Morphol., in press.

Zeuthen, E., 1953. Growth as related to the cell cycle in single cell cultures of Tetrahymena pyriformis. J. Embryol. Exp. Morphol., 1: 239-249.

Zeuthen, E., 1958. Periodicity in living cells. Adv. Biol. Med. Phys., 6: 37-73.

Zeuthen, E., and K. Hamburger, 1956. Cited by Scherbaum, O., 1956. Cell growth in normal and synchronously dividing mass cultures of Tetrahymena pyriformis. Exp. Cell Res., $11: 464-476$.

Zeuthen, E., And O. Scherbaum, 1954. Synchronous divisions in mass cultures of the ciliate protozoan Tetrahymena pyriformis, as induced by temperature changes. Proc. 7 th Symp. Colston Res. Soc., pp. 141-156. 


\section{$2 \mathrm{BHL}$ Biodiversity Heritage Library}

Holz, George G. 1960. "Structural and functional changes in a generation in Tetrahymena." The Biological bulletin 118, 84-95.

https://doi.org/10.2307/1539059.

View This Item Online: https://www.biodiversitylibrary.org/item/110976

DOI: https://doi.org/10.2307/1539059

Permalink: https://www.biodiversitylibrary.org/partpdf/2124

\section{Holding Institution}

Smithsonian Libraries

\section{Sponsored by}

Biodiversity Heritage Library

\section{Copyright \& Reuse}

Copyright Status: In copyright. Digitized with the permission of the rights holder.

License: http://creativecommons.org/licenses/by-nc-sa/3.0/

Rights: https://biodiversitylibrary.org/permissions

This document was created from content at the Biodiversity Heritage Library, the world's largest open access digital library for biodiversity literature and archives. Visit BHL at https://www.biodiversitylibrary.org. 